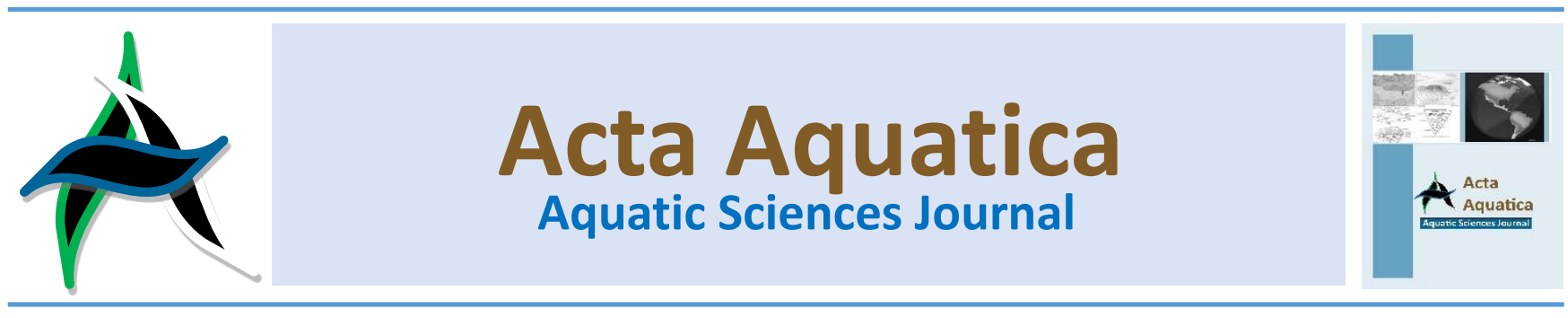

\title{
Aktivitas imunomodulator ekstrak rumput laut
}

\section{Immunomodulator activities in seaweed extract}

\author{
Erniati $^{\text {a, } *}$, dan Riri Ezraneti ${ }^{\text {a }}$ \\ a Program Studi IImu Kelautan, Fakultas Pertanian, Universitas Malikussaleh, Aceh, Indonesia
}

\begin{abstract}
Abstrak
Rumput laut merupakan sumber daya hayati perairan yang telah diteliti mengandung sejumlah komponen bioaktif untuk meningkatkan kesehatan manusia seperti meningkatkan sistem imun atau bersifat sebagai imunomodulator.Penulisan artikel ini bertujuan untuk menjelaskan lebih jauh tentang sifat imunomodulator rumput laut, diharapkan tulisan ini dapat memberikan informasi ilmiah tentang rumput laut sebagai imunomodulator, sehingga nantinya dapat dikembangkan lagi penelitian ilmiah tentang pemanfaatan rumput laut sebagai imunomodulator.Rumput laut dapat meningkatkan sistem imun spesifik dan non spesifik melalui berbagai sel imun seperti sel makrofag, monosit atau sel limfosit melalui berbagai mekanisme di tingkat seluler.Sifat imunomodulator rumput laut dalam meningkatkan aktivasi makrofag terjadi melalui peningkatan proliferasi makrofag, produksi NO dan sekresi sitokin. Rumput laut juga dapat memodulasi aktivitas makrofag secara in vitro dan in vivo yaitu melalui ekspresi reseptor dan sitokin inflamasi seperti tumor necrosis factor (TNF- $\alpha$ ) dan interleukin-16 (IL-16)., produksi NO dan PGE2 dan ekspresi gen NOS-2 dan COX-2. Sifat imunomodulator rumput laut juga terjadi melalui peningkatan fungsi dan aktivitas limfosit. Ekstrak atau komponen bioaktif rumput laut dapat meningkatkan aktivasi limfosit, diantaranya menstimulasi aktivitas sel limfosit B yaitu melalui peningkatan produksi antibodi imonoglobulin (Ig), meningkatkan proliferasi sel T dan produksi subset limfosit T seperti $C D 4$ dan CD8. Ekstrak rumput laut juga telah diteliti mempengaruhi ekspresi mRNA untuk meningkatkan produksi sitokin oleh Th1 seperti TNF- $\alpha$ dan IFN- $\gamma$, dan menurunkan sitokin yang diproduksi oleh Th2 seperti IL-4 dan IL-10 serta meningkatkan produksi IL-2 pada sel limfosit $\mathrm{T}$.
\end{abstract}

\begin{abstract}
Seaweed is one of the marine biological resources that is known to contain bioactive compounds to improve human health, such as enhancing the immune system or being as an immunomodulator. This study aims to explain more about the nature of seaweed immunomodulators so that scientific research could be developed in the use of seaweed as an immunomodulator later. Seaweed could increase specific and nonspecific immune systems by involving various immune cells such as macrophage cells, monocytes, or lymphocyte cells through various mechanisms at the cellular level. The role of Immunomodulatory properties of seaweed in increasing macrophage activation occurs through increasing macrophage proliferation, NO production, and cytokine secretion. Seaweed would modulate macrophage activity in vitro and in vivo through the expression of inflammatory receptors and cytokines such as tumor necrosis factor (TNF- $\alpha$ ) and interleukin-1 $\beta$ (IL-1 $\beta$ ), NO and PGE2 production and NOS-gene expression 2 and COX2. Seaweed immunomodulatory activity would also occur through increasing function and activity of lymphocytes that stimulate the activity of B lymphocyte cells, production of antibody immunoglobulin (Ig), $T$ cell proliferation and production of $\mathrm{T}$ lymphocyte subsets such as CD4 and CD8. Seaweed extracts also have been investigated to be able to affect mRNA expression to increase cytokine production by Th1 such as TNF- $\alpha$ and IFN- $\gamma$, decrease cytokines produced by Th2 such as IL-4 and IL-10 and increase IL-2 production in T lymphocytes.
\end{abstract}

Keywords: seaweed; bioactive components; immunomodulatory; macrophage

Kata kunci: rumput laut; komponen bioaktif; imunomodulatori; makrofag

\section{Pendahuluan}

Rumput laut merupakan sumber daya hayati perairan yang telah diteliti mengandung sejumlah komponen bioaktif

*Korespondensi penulis: Program Studi Ilmu Kelautan, Fakultas Pertanian, Universitas Malikussaleh, Aceh Utara, Aceh, Indonesia. yang dapat meningkatkan kesehatan manusia.Salah satu 
manfaat rumput laut dalam meningkatkan kesehatan manusia adalah potensi rumput laut sebagai imunomodulator. Imunomodulator merupakan suatu substansi atau senyawa kimia yang dapat memodulasi fungsi dan aktivitas sistem imun tubuh (Wiedosari, 2007). Sistem imun merupakan sistem biologis tubuh yang sangat kompleks, terjadi melalui berbagai mekanisme untuk melindungi dan mempertahankan tubuh dari mikroorganisme yang menyerang (Tjandrawinata et al., 2005; Patil et al., 2012). Manfaat imunomodulator dikarenakan kemampuannya untukmenstimulasi mekanisme sistem imun, baik sistem imun spesifik (adaptive) dan non spesifik (innate) sehingga dapat meningkatkan sistem imun individu secara menyeluruh. Adanya fungsi dan aktivitas sistem imun yang baik, dapat menekan sejumlah penyakit dan memelihara kesehatan (Alamgir \& Uddin, 2010; Benny \& Vanitha, 2010).

Berbagai bahan hayati telah diteliti berpotensi sebagai imunomodulator, seperti ekstrak rosella dapat meningkatkan sistem imun tubuh melalui mekanisme penurunan senyawa inflamasi (Mardiah et al., 2015); ekstrak meniran bersifat sebagai imunostimulan pada mencit (Aldi et al., 2013); jahe dapat meningkatkan sistem imun baik secara in vitro maupun in vivo (Zakaria et al., 2003); lidah buaya dapat meningkatkan sistem imun melalui beberapa mekanisme (Wiedosari 2007); ekstrak ginseng, sayuran dan buah-buahan, ekstrak daun zaitun juga dapat meningkatkan sistem imun (Alamgir dan Uddin 2016; Shin et al., 2002).

Bahan hayati di lingkungan perairan seperti rumput laut juga telah diteliti bersifat sebagai imunomodulator sehingga dapat meningkatkan sistem imun. Komponen bioaktif rumput laut seperti flavonoid terutama florotanin, karotenoid terutama fukosantin, polisakarida sulfat seperti laminaran,karagenan, agar, fukoidan,ulvan, galaktan sulfat dan lectin dapat meningkatkan sistem imun tubuh melalui berbagai mekanisme reaksi (Kang et al., 2013; Erniati et al., 2018; Barahona et al., 2014; Hosokawa et al., 2010; Liu et al., 2015; Peasura et al., 2016; Bakar et al., 2015).

Berdasarkan latar belakang tersebut maka dalam tulisan ini bertujuan untuk memaparkan lebih jauh tentang mekanisme imunomodulator rumput laut. Diharapkan tulisan ini dapat memberikan informasi ilmiah tentang mekanisme komponen bioaktif dalam rumput laut sebagai imunomodulator dan sejauh mana penelitian pemanfaatan rumput laut sebagai imunomodulator yang telah dilakukan, sehingga nantinya dapat dikembangkan lagi penelitian-penelitian ilmiah tentang pemanfaatan rumput laut sebagai imunomodulator alami, baik dikonsumsi sebagai sediaan obat atau sebagai produk pangan fungsional.

\section{Pengertian sistem imun dan imunomodulator}

Sistem imun adalah semua mekanisme yang digunakan tubuh untuk melindungi dan mempertahankan tubuh dari bahan asing atau mikroorganisme yang menyerang tubuh (Tjandrawinata et al., 2005).Fungsi sistem imun bagi tubuh ada tiga.Pertama sebagai pertahanan tubuh yakni menangkal partikel atau senyawa asing.Kedua, untuk keseimbangan fungsi tubuh terutama menjaga keseimbangan komponen yang sudah tidak berfungsi, dan ketiga sebagai pemberi sinyal (surveillence immune system), untuk menghancurkan sel-sel yang bermutasi atau ganas. Pada prinsipnya jika sistem imun seseorang bekerja optimal, maka tidak akan mudah terkena penyakit, sistem keseimbangan tubuh juga normal (Nagarathna, 2013).

Secara umum sistem imun terdiri atas sistem imun nonspesifik (innate) dan spesifik (adaptive). Sistem imun nonspesifik bersifat tidak spesifik, tetapi aktivitas sistem imunnya terjadi lebih cepat karena tidak melibatkan sel memori. Sedangkan pada sistem imun spesifik akan dapat mengenali patogen atau mitogen asing yang pernah terpapar sebelumnya sehingga dapat memberikan respon imun yang lebih baik karena melibatkan sel memori. Sistem imun spesifik dan nonspesifik, keduanya masing-masing memiliki dua komponen, yaitu imunitas humoral dan imunitas seluler.Pada sistem imun nonspesifik seluler terdapat keteribatan sistem makrofag-monosit, sedangkan pada sistem humoral melibatkan aktivasi sistem komplemen. Pada sistem imun spesifik seluler terdiri dari sel limfosit $T$ dan sistem imun spesifik humoral melibatkan sel limfosit B. Kedua sistem imun tubuh (spesifik dan non spesifik) tersebut bekerja sama dalam mempertahankan keseimbangan tubuh (Patil et al., 2012; Baratawidjaya \& Rengganis, 2010).

Berbagai bahan asal tanaman dapat memacu fungsi berbagai komponen sistem imun nonspesifik (fagosit, sel NK) dan sistem imun spesifik (proliferasi sel $T$, sel $B$ yang memproduksi antibodi) serta produksi sitokin (Baratawidjaya \& Rengganis, 2010; Anderson, 1999). Berbagai bahan atau senyawa yang dapat memacu sistem imun disebut imunomodulator. Wiedosari (2007) menyatakan imunomodulator merupakan suatu substansi atau senyawa yang dapat memodulasi fungsi dan aktivitas sistem imun tubuh. Imunomodulator dibagi menjadi tiga kelompok, yaitu: (1) imunostimulator berfungsi untuk meningkatkan fungsi dan aktivitas sistem imun, (2) imunoregulator, yaitu dapat meregulasi sistem imun, dan (3) imunosupresor yaitu dapat menghambat atau menekan aktivitas sistem imun (Block dan Mead, 2003). Nagarathna (2013) menyatakan secara umum terdapat dua tipe imunomodulator berdasarkan efek yang diberikan, yaitu immunosupresor dan imunostimulator. Imunostimulator merupakan bahan-bahan yang mampu memacu peningkatan respon imun, baik respon imun spesifik atau non spesifik (Alamgir \& Uddin, 2010).

\section{Potensi komponen bioaktif rumput laut sebagai imunomodulator melalui aktivasi makrofag}

Makrofag merupakan salah satu sel imun penting dalam sistem spesifik dan nonspesifik.Secara normal makrofag selalu ada di dalam tubuh dan tersebar di seluruh jaringan tubuh (Besung et al., 2016). Sel makrofag sangat penting dalam pertahanan homeostatis tubuh dari berbagai kondisi eksternal dan juga merupakan pertahanan yang utama terhadap patogen dan sel lain yang menyerang termasuk sel kanker (Gamal-Eldeen et al., 2007). Peningkatan kemampuan sel makrofag atau yang dikenal dengan aktivasi makrofag adalah kemampuan secara morfologis, metabolisme, dan fungsional dalam pelenyapan agen infeksi di dalam tubuh. Meningkatnya kemampuan ini ditandai dengan meningkatnya aktivitas makrofag, kapasitas fagosit makrofag, dan produksi interleukin (Besung et al., 2016). Aktivasi makrofag ini mempunyai kemampuan yang tinggi dalam melakukan penelanan benda asing melalui proses fagositosis. Sel-sel ini akan menghancurkan semua benda asing seperti kuman, sel-sel yang rusak, sel-sel tumor, benda-benda koloid, dan molekul-molekul besar (Chanana et al., 2007). Aktivasi makrofag juga dapat melepaskan berbagai komponen imunomodulator seperti $N O, I L-1, T N F-\alpha$, intermediet oksigen reaktif danzat lain, untuk menghilangkan patogen dan menghambat pertumbuhan sel asing.NO yang dilepaskan dari makrofag merupakan radikal bebas yang sangat reaktif dan memainkan peranan penting dalam pengaturan berbagai respon imun (Kim et al., 2011). Aktivasi makrofag ini juga merupakan tahap awal transfer bioinformasi untuk menghasilkan aktivitas imunomodulator (Peasure et al., 2016). 
Peranan komponen bioaktif rumput laut sebagai imunomodulator melalui mekanisme aktivasi makrofag telah dilaporkan (Peasure et al., 2016; Perez-Recalde et al., 2014; Wang et al., 2013; Zha et al., 2015; Cao et al., 2014; Tabarsa et.al. 2012; Fang et al., 2015). Ekstrak rumput laut Gelidium amansii dapat memodulasi aktivitas makrofag melalui peningkatan proliferasi makrofag, produksi NO dan sekresi sitokin (Wang et al., 2013). Fraksi polisakarida asam larut air dari rumput laut hijau Ulva rigida dapat memodulasi aktivitas makrofag pada sel RAW264 tikus secara in vitro yaitu melalui ekspresi reseptor dan sitokin inflamasi, produksi nitric oxide (NO) dan prostaglandin E2 (PGE2) dan ekspresi gen nitric oxide synthase 2 (NOS-2) dan cyclooxygenase-2 (COX-2) (Leiro et al., 2007). Peasure et al. (2016) menyatakan bahwa hasil fraksinasi polisakarida sulfat dari rumput laut hijau Ulva intestinalis dapat mengaktifasi sel makrofag J774A.1 dengan menstimulasi produksi NO, tumor necrosis factor (TNF- $\alpha$ ) dan interleukin-16 (IL-16). Perez-Recalde et al. (2014) melaporkan bahwa polisakarida sulfat yaitu fraksi xylomannan dan mannan dari rumput laut merah Nemalion helminthoides dapat menstimulasi sel makrofag RAW 264.7 tikus secara in vitro dengan memproduksi NO, TNF- $\alpha$ dan sitokin IL-6. secarain vitro dan secara in vivo dapat meningkatkan jumlah sitokin serum darah tikus yang sebelumnya telah diberikan ekstrak polisakarida sulfat melalui pembuluh vena.

Fang et al. (2015) juga melaporkan ekstrak polisakarida larut air dari rumput laut Laminaria japonica dapat mengaktivasi sel makrofag dan menstimulasi produksi NO dan sitokin TNF- $\alpha, I L-1, I L-6$ dan IL-10 dan mengatur ekspresi gen dari sitokin TNF- $\alpha, I L-1, I L-6$ dan IL-10 secara in vitro. Pada penelitian tersebut juga menjelaskan bahwa polisakarida larut air dari rumput laut Laminaria japonica bersifat imunomodulator pada reaksi inti translokasi NF-kBp65 dari sitoplasma menuju inti sel dan fosforilasi $I k B \alpha, E R K 1 / 2, J N K 1 / 2$ dan P38 sel makrofag. Analisis dengan flow cytometer dan confocal laser-scanning microscopy menunjukkan bahwa polisakarida larut air dari rumput laut bersifat imunomodulator melalui aktivasi Toll like receptor (TLR) seperti TLR4 yang melibatkan aktivasi jalur mitogen-activated protein kinase (MAPK) dan NF-kB.

Fucan sulfat larut air yang diisolasi dari rumput laut Ecklonia cava dapat menginduksi stimulasi sel RAW264 memproduksi sejumlah oksida nitrat dan sitokin, yaitu dengan menginduksi degradasi $l k-B$ dan phosforilasi $M A P K$ melalui aktivasi jalur NF-kB dan jalur MAPK (Cao et al. 2014). Cho et al., (2014) melaporkan fukoidan dari Agarum cribrosum juga dapat mengaktivasi jalur NF-kB dan MAPK sehingga terjadi ekspresi transkripsi iNOS, COX-2 dan IL-10.

NO merupakan mediator inflamasi penting yang diproduksi dan diaktifkan oleh makrofag. NO berkontribusi untuk pembunuhan mikroorganisme pathogen dan sel tumor serta berfungsi sebagai molekul pembawa pesan intraseluler untuk memediasi berbagai fungsi biologis (Liew et al., 1995). Peningkatan produksi NO karena aktivasi makrofag oleh polisakarida sulfat rumput laut kemungkinan disebabkan karena polisakarida sulfat dapat berikatan dengan reseptor makrofag, sehingga akan mengaktivasi makrofag yang menyebabkan peningkatan produksi NO. Pengikatan polisakarida sulfat rumput laut pada permukaan reseptor makrofag kemungkinan terjadi melalui Toll-Like 4 Receptor (TLR-4). Pengikatan ini akan mengaktivasi mitogen activated protein kinase (MAPK) yang terkait dengan signal kinase ekstraseluler. Kinase dapat mempromosikan ekspresi gen inflamasi seperti NOS yang akan memproduksi NO (Peasure et al., 2016; Leiro et al., 2007; Tsuji et al., 2003; Akira, 2000).
Schepetkin dan Quinn (2006) mengemukakan bahwa polisakarida rumput laut sama halnya dengan polisakarida tanaman lainnya diduga dapat mengaktivasi makrofag melalui ikatan polisakarida dengan reseptor spesifik. Reseptor merupakan molekul penanda yang dapat mengenali adanya ligan asing pada fase awal respon imun. Secara khusus, polisakarida atau glikoprotein rumput laut dapat berikatan dengan makrofag melalui reseptor spesifik yaitu : TLR4,CD14, complement receptor $3(C R 3)$, scavenger receptor $(S R)$, dectin-1 dan mannose receptor $(M R)$. Ikatan polisakarida dengan reseptor spesifik kemungkinan akan menghasilkan kerjasama dua reseptor membentuk cluster komplek signal, misal signal $S R-C R 3$, dimana signal $S R-C R 3$ menyebabkan aktivasi fosfolipase-C $(P L C), P L C$ ini akan menghasilkan protein kinase $C$ $(P K C)$ dan phosphoinositide-3-kinase (PI3K). Kerjasama kedua protein ini akan mengaktivasi MAPK, signal ekstraselulerERK) dan nuclear factor-kB (NF-kB), dimana akhirnya jalur ini akan menginduksi transkripsi gen. Aktivasi $M R$ menyebabkan aktivasi fagositosis, produksi oksidan, endositosis dan NF-kB. Pengikatan ligan TLR4 menghasilkan aktivasi IL-1Rassociated kinase (IRAK) melalui adaptor dengan myeloid differentiation protein88 (MyD88) yang berikutnya mengakibatkan aktivasi TNF receptor-associatedfactor 6 (TRAF-6), MAP kinases (misal p38 dan $J N K$ ) dan NF-kB. Aktivasi jalur ini akan menginduksi ekspresi sitokin pro-inflamasi dan inducible nitric oxide synthase (iNOS) (Schepetkin \& Quinn, 2006).

Usmiati (2017) menyatakan bahwa aktivasi makrofag oleh polisakarida berhubungan dengan produksi sitokin yang diperlukan untuk menjalankan fungsi imun.Aktivasi ini dimediasi oleh sejumlah kompleks ligan+reseptor spesifik pada membran. Reseptor utama sel makrofag untuk pengenalan polisakarida adalah glikoprotein yang terdiri dari TLR4, CD14, CR3 dan SR. Reseptor-reseptor tersebut akan mengaktivasi jalur sinyal intraseluler dan MAPK.

\section{Peningkatan fungsi limfosit oleh ekstrak rumput laut}

Limfosit termasuk salah satu jenis leukosit (sel darah putih) yang mempunyai peranan penting dalam mekanisme sistem imun tubuh. Limfosit akan memberikan respon terhadap suatu substansi benda asing (antigen) yang masuk ke dalam tubuh melalui sistem imunitas seluler maupun imunitas humoral (Koolman \& Rohm, 2001). Limfosit terdiri dari limfosit $\mathrm{T}$ dan limfosit B yang berperan dalam respon imun seluler. Kemampuan mengenal benda asing oleh limfosit disebabkan oleh adanya reseptor pada permukaan sel. Reseptor sel T (TCR) dapat mengenal peptida antigen yang terikat dengan molekul penyaji MHC (Mayor Histocompatibility Complex) (Baratawijaya \& Rengganis, 2010).

Limfosit $T$ terdiri dari sel Th ( $T$ helper) dan limfosit $T c$ ( $T$ cytotoxit ). CD4 merupakan molekul penanda untuk $\mathrm{T}$ helper. CD4 akan mengaktivasi sel limfosit $\mathrm{T}$ dan menginduksi respon imun seluler. CD8 merupakan molekul penanda limfosit $T$ cytotoxit.Sel $\mathrm{T}$ helper merupakan bagian dari limfosit yang memegang peran penting dalam mengaktivasi dan mengarahkan sel imun lainnya untuk menangani se lasing yang masuk. Sel T helper juga berperan penting dalam proliferasi sel $T$ cytotoxit maupun meningkatkan aktivitas fagositik makrofag.CD8 mempunyai efek sitotoksit. Rasio CD4/CD8 menggambarkan fungsi aktivasi atau penghambatan sistem imun. Senyawa bioaktif yang bersifat imunomodulator akan meningkatkan jumlah CD4 sel limfosit (Baeke et al., 2010; Takahasyi et al., 2014; Zhu et al., 2012; Yan et al., 2014; Roit et al., 2011). 
Peningkatan sistem imun melalui proses aktivasi sel imun dapat terjadi jika sel terpapar senyawa asing atau antigen atau adanya kerusakan jaringan. Salah satu sel imun yang teraktivasi adalah sel limfosit. Proses aktivasi limfosit secara umum dibagi menjadi 3 fase, yaitu fase induksi, fase ekspansi, dan fase efektor. Pada fase induksi diawali dengan terjadinya pengikatan antigen ke reseptor spesifik limfosit.Limfosit $T$ mengenal antigen yang berikatan dengan $\mathrm{MHC}$ yang disajikan oleh $A P C$.Respon imun diawali oleh masuknya antigen yang disajikan APC ke dalam sel. melalui TCR. Pada fase ekspansi limfosit yang telah mengalami induksi oleh antigen akan berproliferasi dengan cepat sehingga jumlahnya banyak dan mengaktifkan molekul sitokin seperti IL-2 serta mengaktifkan sistem mikrofag dan sel B. Pada fase efektor akan diaktifkan mekanisme efektor sel imun untuk mengeliminasi antigen atau benda asing lainnya sehingga dapat menyebabkan destruksi, sitotoksisiti dan apoptosis (Barret et al., 2003; Li et al., 2013).

Proses aktivasi limfosit menyebabkan terjadinya peningkatan sintesis ATP, sintesis $R N A$, replikasi $D N A$, produksi sitokin dan ekspresi protein pada permukaan sel (Wieland, 2016). Pada sistem imun spesifik, binding antigen dimediasi oleh TCR.TCR adalah molekul yang digunakan sel T untuk mengenal antigen dan merupakan protein yang terikat pada membran dan berfungsi sebagai pemberi signal pada sel $T$ sehingga mengalami aktivasi. Antigen disajikan oleh APC, dimana pada $M H C$ kelas II akan beriteraksi dengan sel $C D 4$, sedangkan pada MHC kelas I akan berinteraksi dengan CD8. Binding reseptor dengan antigen akan menyebabkan aktivasi berbagai jalur signal. Jika limfosit terpapar dengan antigen, maka terjadi ikatan kompleks MHC-peptida antigen (dipresentasikan oleh $A P C$ ). Proses aktivasi sel limfosit diawali oleh interaksi antara komplek TCR-CD3 dengan MHC-peptida, ikatan ini akan menginduksi sinyal untuk aktivasi sel $T$ (Baratawijaya \& Rengganis, 2010).

Aktivasi sel limfosit akan menimbulkan berbagai reaksi biokimia di dalam sel T seperti perombakan fosfatidil-inositol dan peningkatan konsentrasi ion $\mathrm{Ca} 2+$ serta aktivasi protein kinase-C yang dibutuhkan sebagai katalisator pada fosforilasi berbagai jenis protein yang terlibat. Aktivasi protein tersebut mengakibatkan serangkaian reaksi yang menghasilkan ekspresi reseptor IL-2 dan produksi IL-2 yang dibutuhkan untuk proliferasi sel selanjutnya. Sebagian sel T akan berfungsi sebagai sel $\mathrm{T}$ helper-inducer untuk membantu sel $\mathrm{B}$, dan sebagian lagi akan kembali dalam keadaan istirahat sebagai sel $\mathrm{T}$ memori (Roitt et al., 2011).

Proses aktivasi sel limfosit dapat dipelajari secara in vitro menggunakan model kultur sel. Secara umum penanda aktivasi limfosit dapat dipelajari melalui analisis molekul penanda permukaan sel limfosit (surface marker). Penanda limfosit $T$ dapat dipelajari dengan menganalisis jumlah CD3 dan sub set limfosit yang distimulasi oleh antigen. Molekul penanda untuk sel B adalah CD2O dan molekul penanda untuk sel NK adalah CD16 (Ulmer et al., 2000).Limfosit yang teraktivasi dapat diamati terutama pada sel T, sel B dan sel NK.Limfosit T yang teraktivasi ditandai oleh ekspresi molekul penanda pada permukaan sel, meliputi protein reseptor, molekul costimulator, molekul adhesi, reseptor chemokin dan MHC-II seperti digambarkan pada Gambar 1.

Komponen bioaktif rumput laut telah diteliti bersifat imunomodulator melalui proses aktivasi limfosit dengan berbagai proses imun dan melibatkan berbagai mekanisme (Zailanie et al., 2015; Ahn et al., 2008; Ahn 2011; Ahn 2013; Liu et al., 1997; Shan et al., 1999; Subaryono, 2017). Ekstrak rumput laut mempunyai kemampuan menstimulasi aktivitas sel limfosit B, yaitu dengan meningkatkan aktivitas proliferasi sel B dengan meningkatkan produksi antibodi imonoglobulin (Ig) (Liu et al., 1997)

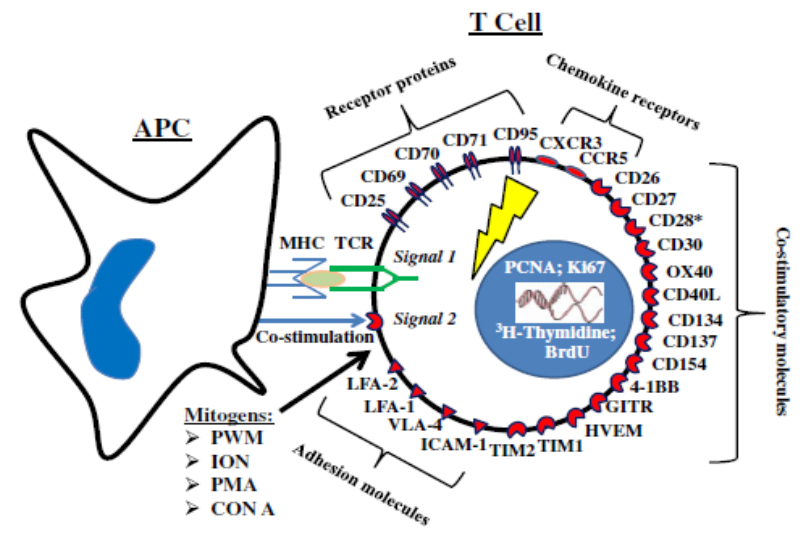

Gambar 1. Molekul penanda limfosit yang teraktivasi (Chipkova dan Wieland 2012)

Ekstrak enzimatis oligosakarida alginat (OSA) rumput laut coklat Sargassum crassifolium dapat menginduksi proliferasi limfosit manusia secara in vitro, dimanasel limfosit yang diinduksi proliferasinya adalah sel $C D 8$ atau sel $T C$ serta sel non $C D 4 / C D 8$. OSA dapat menginduksi proliferasi limfosit diduga karena OSA dapat berikatan dengan binding site dar limfosit, dan mengaktivasinya untuk berproliferasi.Mekanisme induksi proliferasi sel limfosit oleh OSA diperkirakan mirip dengan mekanisme induksi proliferasi limfosit oleh lipopolisakarida (LPS), dikarenakan struktur kimia yang mirip (Subaryono, 2016). Aktivasi sel limfosit oleh LPS membutuhkan binding site yang tidak harus melibatkan major histocompatibility complex $(\mathrm{MHC})$, tetapi sangat dipengaruhi oleh co-stimulatory signal yang dihasilkan oleh interaksi antara B7 dan CD28 (Ulmer et al., 2000).

Shan et al. (1999) menyatakan bahwa ektrak rumput laut hijau Hizikia fusiformis dan Meristotheca papulosa dapat menstimulasi proliferasi limfosit $\mathrm{T}$ dan limfosit B, tetapi tidak meningkatkan jumlah sel NK. Mekanisme stimulasi limfosit $T$ terjadi melalui peningkatan aktivitas sel Tc dan menstimulasi produksi imunoglobulin $(I g)$ oleh sel B secara in vitro. Penelitian ini juga membuktikan bahwa ekstrak rumput laut hijau Hizikia fusiformis dan Meristotheca papulosa juga menginduksi produksi sitokin seperti TNF- $\alpha$ yang diekspresikan oleh sel T efektor.

Ekstraks enzimatis Eclonia. cava (ECK) dapat meningkatkan jumlah $C D 4+, C D 8+$ sel T dan $C D 45$ sel B. Ekstrak ECK juga dapat mempengaruhi ekspresi mRNA untuk meningkatkan produksi sitokin oleh Th1 seperti TNF- $\alpha$ dan IFN$\gamma$, dan menurunkan sitokin yang diproduksi oleh Th2 seperti IL4 dan IL-10 (Ahn et al., 2008). Ahn et al. (2008) melaporkan bahwa ECK bersifat imunomodulator melalui peningkatan jumlah populasi sel T yaitu dengan meningkatkan produksi $I L-2$ pada sel limfosit T. IL-2 adalah sitokin yang sangat penting pada proses aktivasi sel $T$ karena merupakan sitokin yang bertanggung jawab pada proses stimulasi terjadinya proliferasi limfosit (Paul \& Selder, 1998), meningkatkan proses perbanyakan sel $T$ dan mengatur signal selama proses aktivasi limfosit (Boise \& Thomson, 1998). IL-2 juga merupakan sitokin yang berperan dalam proses aktivasi, proliferasi dan diferensiasi sel B dalam membentuk immunoglobulin (Soeroso, 2007).

Ekstrak enzimatis rumput laut Ecklonia cava dapat menstimulasi aktivasi dan proliferasi sel limfosit melalui mekanisme aktivasi jalur NF-KB.Ektrak enzimatis rumput laut Ecklonia cava menyebabkan degradasi $I \kappa B$, aktivasi $N F-\kappa B$ dan upregulasi jumlah IKBamRNA. Selanjutnya kompleks $p 50 / p 65$ 
menginisiasi jalur $N F-K B$, promosi transkripsi gen esensial untuk produksi sitokin seperti $I L-2$ yang akan meningkatkan aktivasi, proliferasi dan diferensiasi limfosit. Pada penelitian ini membuktikan bahwa peningkatan proliferasi dan produksi IL-2 oleh ekstrak rumput laut Ecklonia cava terjadi melalui jalur NF$\kappa B$ yang melibatkan fosforilasi molekul IKB $\alpha$ dan aktivasi $N F-K B$ p65 dan DNA yang mengikatnya. NF-KB merupakan faktor utama yang berperan dalam proses transkripsi gen termasuk gen yang berperan dalam respon imun yaitu proses proliferasi/diferensiasi dan tranformasi sel (Ahn et al., 2011).

Selain melalui jalur NF- $k B$, peningkatan produksi IL-2 oleh $E C K$, kemungkinan juga melibatkan jalur signal lainnya misalnya jalur yang melibatkan protein kinase ekstraseluler misalnya $E R K I$, p38 atau JNK yang diaktifkan melalui TCR dan IL1 (Ahn et al., 2011). Polisakarida sulfat rumput laut kemungkinan juga memberikan respon untuk aktivasi jalur TLR4 dan aktivasi proliferasi limfosit melalui jalur klasik NF-kB melalui aktivasi JNK (Ahn et al., 2013). Zhang et al. (2016) juga melaporkan bahwa TLR4 dapat berinteraksi dengan polisakarida, termasuk polisakarida rumput laut. Polisakarida dari tanaman lain telah dilaporkan dapat menginduksi limfosit memproduksi/L-1, IL-6, IFN- $\gamma$ dan TNF- $\alpha$ dan mengaktivasi jalur signal MAPK dan signal NFKB melalui TLR4 (Shao et al., 2004). Telah diketahui bahwa MAPK, ERK1/2, and ERK5 merupakan protein penting untuk mengontrol produksi IL-2.Jalur signaling ERK diperlukan pada saat terjadi stimulasi sel limfosit $\mathrm{T}$ dan $\mathrm{B}$ oleh mitogen (Ahn, 2013).

Toll-like receptors (TLR) termasuk kelompok glikoprotein yang berfungsi sebagai reseptor permukaan transmembran dan terlibat dalam respons imun. TLR merupakan komponen kunci pada respons imun non spesifik yang dapat mengenali komponen mikroorganisme. Selanjutnya $T L R$ memulai jalur yang memberi sinyal untuk mengaktifkan sitokin, kemokin, dan peptida antimikroba (Petry \& Gaspari, 2006). TLR dapat meningkatkan pengikatan dan pengaturan molekul costimulasi yang terlibat dalam respons imun spesifik dan non spesifik.Jadi dapat dikatakan bahwa TLR mempunyai peranan penting dalam respon imun spesifik dan spesifik dalam memberikan respon imun terhadap mikroorganisme atau pathogen.Sel imun limfosit merupakan salah satu sel imun yang mengekspresikan TLR pada sistem imun spesifik (Kabayasi, 2008 dalam Hikmah \& Dewanti 2011). Gambar 2 menyajikan peranan TLR pada imunitas nonspesifik yang dapat menimbulkan reaksi imunitas spesifik.

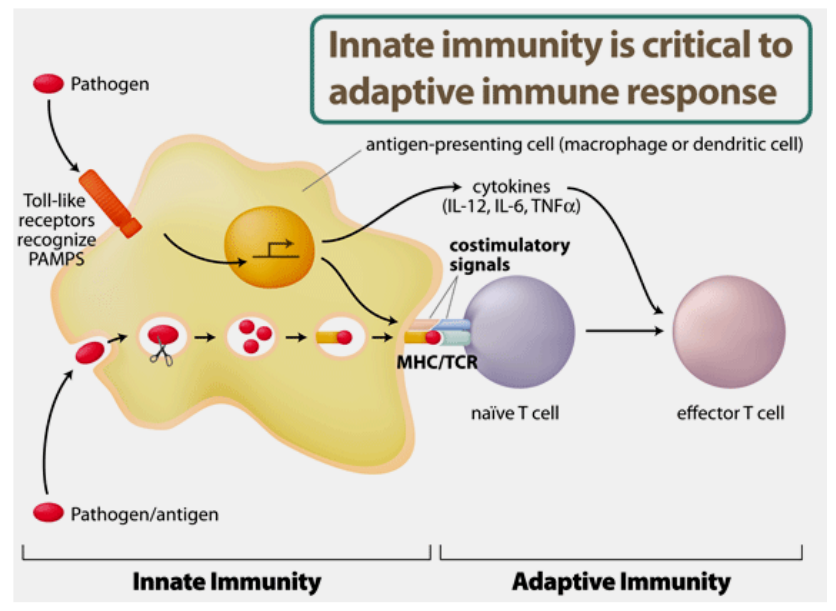

Gambar 2. Peranan TRL pada imunitas non spesifik dan menimbulkan reaksi imunitas spesifik (Kabayasi, 2008 dalam Hikmah \& Dewanti, 2011)

Pada imunitas non spesifik, patogen dikenali $T L R$, menimbulkan signal (tanda) dalam sel dan mempengaruhi ekspresi sitokin.Patogen juga dapat diekspresikan makrofag dalam MHC dan menimbulkan reaksi imunitas spesifik (Kabayasi, 2008 dalam Hikmah \& Dewanti, 2011).

Peran $T L R$ dalam perkembangan limfosit $T$ sangat dominan, meliputi: TLR4 dan TLR9 berhubungan dengan perkembangan limfosit Th1, sedangkan TLR2 dan TLR5 berperan dalam perkembangan limfosit Th2. TLR3 berperan dalam menyajikan antigen tumor/viral oleh sel dendritik yang akan disajikan ke limfosit $T c$ serta memodulasi dan meregulasi toleransi limfosit T (Redecke et al., 2004).

$T L R$ dapat menginisiasi respon imun spesifik, yaitu dapat langsung memodulasi fungsi sel T. TLR2, TLR3, TLR5 dan TLR9 bertindak sebagai reseptor costimulasi meningkatkan proliferasi dan produksi sitokin pada sel limfosit yang distimulasi oleh TCR. Selain itu TLR2, TLR5 dan TLR8 dapat memodulasi aktivitas yang $C D 25+C D 4$ + pada sel T limfosit (Kabelitz, 2007).

\section{Aktivitas imunomodulator rumput laut sebagai anti-inflamasi}

Inflamasi adalah respon fisiologis tubuh terhadap kerusakan atau adanya gangguan faktor luar, dimana respon tersebut akhirnya ditujukan untuk pemulihan struktur dan fungsi jaringan tubuh (Yoo et al., 2012). Respon fisiologis in melibatkan sistem imun spesifik dan non spesifik. Proses inflamasi yang berkepanjangan berkontribusi terhadap patogenesis banyak penyakit seperti radang sendi, asma, multiple sclerosis, penyakit usus dan aterosklerosis (Rankin 2004). Inflamasi ini merupakan proses kompleks yang melibatkan mediator inflamasi dan sel inflamasi (Sacca et al.,1997).

Pengobatan untuk inflamasi pada umumnyaditujukan untukmenghambat aktivitas sel-sel inflamasi atau menghambat produksi mediator inflamasi (Shu et al., 2013). Komponen bioaktif rumput laut telah diteliti memiliki efek anti inflamasi (Wang et al., 2013; Kim et al., 2010; Shu et al., 2013; Yoo et al., 2012). Ekstrak Gelidium amansii memiliki efek anti-inflamasi dengan menekan produksi sitokin proinflamasi seperti TNF- $a, I L-$ 6 , dan IL-16. Mekanisme yang mungkin untuk anti-inflamasi ekstrak Gelidium amansii adalah dengan memblok translokasi NF-kB dan down-regulasi ekspresi protein inducible nitric oxide synthase (iNOS) (Wang et al., 2013).

Senyawa fukosantin yang diisolasi dari rumput laut coklat Ishige okamurae mempunyai efek anti-inflamasi dengan cara menghambat mediator proinflamasi yaitu NO, PGE2, IL-1B, $T N F-\alpha$, dan IL- 6 melalui penghambatan aktivasi NF-KB dan menekan phosphorilasi MAPK pada sel makrofag RAW 264.7 (Kim et al., 2010). Ekstrak methanol rumput laut merah dari Malaysia Gracilaria changii telah dilaporkan berkhasiat sebagai antiinflamasi karena dapat menghambat ekspresi gen TNF- $\alpha$ dan IL-6 yang terjadi selama proses diferensiasi sel U-397 secara in vitro (Shu et al., 2013).

Fucosterol yang diisolasi dari rumput laut Undaria pinnatifida telah dilaporkan mempunyai efek anti-inflamasi yaitu dengan menekan mediator pro-inflamasi seperti iNOS dan sitokin pro-inflamasi seperti TNF- $\alpha$ dan IL-6 melalui inaktivasi jalur transkripsi $N F-k B$ yaitu dengan mengkoordinasi $I K K / I k B-\alpha-$ dan $M K K 3 / M K K 6 / p 38$ jalur $M A P K$. Proses ini dapat terjadi melalui mekanisme penghambatan proses transkripsi aktivitas mrdiator inflamasi. Fukosterol dapat menghambat aktivitas transkripsi NF- $k B$ dan aktivitas pengikatan dengan DNA sehingga dapat menghambat translokasi p65 dan p50 serta menghambat reaksi phosphorilasi p65. Akibatnya fukosterol dapat menghambat fosforilasi mitogen-activated protein kinase kinases 3/6 (МKK3/MKK6) dan mitogen activated protein kinase-activated protein kinase 2 (MK2), dimana keduanya terlibat dalam jalur p38 MAPK (Yoo et al., 2012). 


\section{Kesimpulan}

Komponen bioaktif rumput laut dapat bersifat sebagai imunomodulator baik dengan meningkatkan sistem imun spesifik maupun non spesifik yang terjadi melalui berbagai meknisme dengan melibatkan sel imun seperti limfosit dan makrofag.

\section{Bibliografi}

Ahn, G., Hwang, I., Park, E., Kim, J., Jeon, Y. J., Lee, J., Park, J. W, Jee, Y., 2008. Immunomodulatory effects of an enzymatic extract from Ecklonia cava on murine splenocytes. Marine Biotechnology. 10(3):278-289. doi: 10.1007/s10126-007-9062-9.

Ahn, G., Park, E., Lee, W. W., Hyun, J. W., Lee, K. W., Shin, T., Jeon, Y. J., Jee, Y., 2011. Enzymatic extract from Ecklonia cava induces the activation of lymphocytes by IL-2 production through the classical NF-KB pathway. Marine Biotechnology. 13(1): 66-73.

Ahn, G., Bing, S. J., Kang, S. M., Lee, W. W., Lee, S. H., Matsuda, H., Tanaka, A., Cho, I. H., Jeon, Y. J., Jee, Y., 2013. The JNK/NFKB pathway is required to activate murine lymphocytes induced by a sulfated polysaccharide from Ecklonia cava. Biochimica et Biophysica Acta (BBA)General Subjects. 1830(3): 2820-2829.

Alamgir, M. Uddin, S. J., 2010. Recent advances on the ethnomedicinal plants as immunomodulatory agents. Ethnomedicine: A Source of Complementary Therapeutics: 227-244.

Aldi, Y., Ogiana, N., Handayani, D., 2013. Uji imunomodulator beberapa subfraksi ekstrak etil asetat Meniran (phyllanthus niruri [I]) pada mencit putih jantan dengan Metoda carbon clearance. Prosiding Seminar Nasional Perkembangan Terkini Sains Farmasi dan Klinik III. Fakultas Farmasi Universitas Andalas Padang.

Anderson, W. L., 1999. Introduction to the Immune System: Innate and Acquired Immunity. Dalam: Immunology. Fence Creek Publishing. Madison: 7-22.

Baeke, F., Korf, H., Overbergh, L., 2010. Human T lymphocytesare direct targets of 1,25-dihydroxyvitamin D3 in the immunesystem. J. Steroid Biochem and Molecular Biol. 121(2): 221-227. doi:10.1016/j.jsbmb.2010.03.037.

Bakar, N. A., Anyanji, V. U., Mustapha, N. M., Lim, S. L., Mohamed, S., 2015. Seaweed (Eucheuma cottonii) reduced inflammation, mucin synthesis, eosinophil infiltration and MMP-9 expressions in asthma-induced rats compared to Loratadine. Journal of Functional Foods.19:710-722.

Barahona, T., Encinas, M. V., Imarai, M., Mansilla, A., Matsuhiro, B., Torres, R., Valenzuela, B., 2014. Bioactive polysaccharides from marine algae. J. Bioact Carbohydr and Diettary Fibre. 4: 125 - 138. doi:org/10.1016/j.bcdf.2014.09.002.

Baratawidjaja, K. G., Rengganis, I., 2010. Imunologi Dasar. Jakarta (ID): Fakultas Kedokteran Universitas Indonesia.
Barrett, A. J., Rezvani, K., Solomon, S., Dickinson, A. M., 2003. New developments in allotransplant immunology. Hematology Am Soc Hematol Educ Program: 50-357.

Benny, K. H., Vanitha, J., 2004. Immunomodulatory and antimicrobial effects of some traditional chinese medicinal herbs: A Review. Current Medicinal Chemistry. 11: 1423-1430.

Besung, I. N., Astawa, N. M., Suata, K., Suwiti, N. K., 2016. Hubungan antara aktivasi makrofag dengan kadar interleukin-6 dan antibodi terhadap salmonella typhi pada mencit (Relationship between the macrophage activity with interleukin- 6 levels and titers of antibodies against Salmonella typhi. Jurnal Kedokteran Hewan. 2016. 10(1): 1-4.

Block, K. I., Mead, M. N., 2003. Immune system effects of Echinaceae, Ginseng and Astragakus. A Review. Integrative Cancer Therapies. 2(3): 247-267.

Boise, L. H., Thomson, C. B., 1998. Hierarchical control of lymphocytes survival. Science. 275: 67-68.

Cao, R. A., Lee, Y., You, S., 2014. Water soluble sulfated-fucans with immune-enhancing properties from Ecklonia cava.International journal of biological macromolecules. 67:303-11. doi.org/10.1016/j.ijbiomac.2014.03.019.

Chan, K. F., Siegel, M. R., Lenardo, J. M., 2000. Signaling by the TNF receptor superfamily and $T$ cell homeostasis. Immunity.13: 419-422.

Chanana, V., Ray, D. B., Rishi, P., 2007. Reactive nitrogen intermediates and monokines induce caspase-3 mediated macrophage apoptosis by anaerobically stressed Salmonella typhi. Clin. Exp. Immunol. 150(2): 368-374.

Chan, K. F., Siegel, M. R., Lenardo, J. M., 2000. Signaling by the TNF receptor superfamily and $\mathrm{T}$ cell homeostasis. Immunity .13: 419-422.

Cho M., Lee, D.J., Kim, J.K., You, S., 2014. Molecular characterization and immunomodulatory activity of sulfated fucans from Agarum cribrosum.Carbohydrate polymers. 113: 507-14.

Erniati., Zakaria, F. R., Prangdimurti, E., Adawiyah, D. R., Priosoeryanto, B. P., and N. Huda., 2018. "Chemical evaluation of nori-like product (geluring) made from the mixture of Gelidium sp. andUlva lactuca seaweeds" Curent Research Nutrition and Food Science; 6(3), 664671.

Fang, Q., Wang, J. F., Zha, X. Q., Cui, S. H., Cao, L., Luo, J. P., 2015. Immunomodulatory activity on macrophage of a purified polysaccharide extracted from Laminaria japonica. Carbohydrate polymers. 134:66-73.

Gamal-Eldeen, A. M., Amer, H., Helmy, W. A., Talaat, R. M., Ragab, H., 2007. Chemically-modified polysaccharide extract derived from Leucaena leucocephala alters Raw 264.7 murine macrophage functions. Intern immunopharmacology. 7: 871-878. 
Golks, A., Tran, T. T., Goetschy, J. F., Guerini, D., 2007. Requirement for Olinked N-acetyl glucosaminyltransferase in lymphocytes activation. EMBO J. 26: 4368-4379.

Granucci, F., Zanoni, I., Feau, S., Ricciardi-Castagnoli, P., 2003. Dendritic cell regulation of immune responses: a new role for interleukin 2 at the intersection of innate and adaptive immunity. The EMBO journal. 22(11): 25462551.

Heo, S. J., Yoon, W. J., Kim, K. N., Ahn, G. N., Kang, S. M., Kang, D. H., Affan, A., Oh, C., Jung, W. K., Jeon, Y. J., 2010. Evaluation of anti-inflammatory effect of fucoxanthinisolated from brown algae in lipopolysaccharide-stimulated RAW 264.7 macrophages. Food Chem Toxicol. 48: 2045-2051. doi:10.1016/j.fct.2010.05.003

Hikmah, N., Dewanti, I. D. A. R., 2011. Peran toll like receptors (t/rs) pada innate immunity. Stomatognatic. 8 (1): 21-26.

Hosokawa, M., Miyashita, T., Nishikawa, S., Tsukui, T., Beppu, F., Okada, T., Miyashita, K., 2010. Fucoxanthin regulates adipocytokine mRNA expression in white adipose tissue of diabetic/obeseKK-Ay mice. Arch. Biochem. Biophys.504: 17-25. doi:10.1016/j.abb.2010.05.031.

Ishimaru, N., Kishimoto, H., Hayashi, Y., Sprent, J., 2006. Regulation of naive T cell function by the NF-kappa B2 pathway. Nat Immunol. 7: 763-772.

Kabelitz, D., 2007. Expression and function of Toll-like receptors in T lymphocytes.Current opinion in immunology. 2007 Feb 28; 19(1): 39-45. doi: 10.1016/j.coi.2006.11.007.

Kang, M. C., Wijesinghe, W. A. J. P., Lee, S. H., Kang, S. M., Ko, S. C., Yang, X., Kang, N., Jeon, B. T., Kim, J., Lee, D. H., Jeon, Y. J., 2013. Dieckol isolated from brown seaweed Ecklonia cava attenuates type II diabetesin $\mathrm{db} / \mathrm{db}$ mouse model. Food and Chem Toxicol. 53:294-298. doi:10.1016/j.fct.2012.12.012.

Kim, J. K., Cho, M. L., Karnjanapratum, S., Shin, I. S., You, S. G., 2011. In vitro and in vivo immunomodulatory activity of sulfated polysaccharides from Enteromorpha prolifera. Inter J. of Biol Macromolecules. 49: 1051- 1058. doi:10.1016 / j.ijbiomac.2011.08.032.

Kim, M. M., Rajapakse, N., Kim, S. K., 2010. Anti-inflammatory effect of Ishige okamurae ethanolicextract via inhibition of NF-kappaB transcription factor in RAW 264.7 cells. Phytother.23: 628-634. doi: 10.1002/ptr.2674.

Koolman, J., dan Rohm, K. H., 2001. Biokimia: Atlas Berwarna dan Teks. Alih Bahasa Sadikin M. Jakarta: Fakultas Kedokteran Universitas Indonesia.

Leiro, J. M., Castro, R., Arranz, J. A., Lamas, J., 2007. Immunomodulating activities of acidic sulphated polysaccharides obtained from the seaweed Ulva rigida C. Agardh. International Immunopharmacology. 7(7): 879-888.

Liew, F. Y., 1995. Interactions between cytokines and nitric oxide. Advances in neuroimmunology. 5(2): 201-209.
Liu, J. N., Yoshida, Y., Wang, M. Q., Okai, Y., Yamashita, U., 1997. $B$ cell stimulating activity of seaweed extracts. International journal of immunopharmacology. 19(3): 135-142.

Liu, J., Willfor, S., Xu, C., 2015. A review of bioactive plant polysaccharides: Biological activities, functionalization, and biomedical applications. Bioactv Carbohydr and Diettary Fibre. 5:31 - 61. doi:org/10.1016/j.bcdf.2014.12.001.

Li, X. C., Kloc, M., Ghobrial, R. M., 2013. Memory T cells in transplantation-progress and challenges. Curr Opin Organ Transplant. 18:387-392.

Mardiah., Zakaria, F. R., Prangdimurti, E., Damanik, R., 2015. Anti-inflammatory of purple roselle extract in diabetic rats induced by streptozotocin. Procedia Food Science. 3: 182 - 189. doi: 10.1016/j.profoo.2015.01.020.

Mora, A. L., Corn, R. A., Stanic, A. K., Goenka, S., Aronica, M., Stanley, S., Ballard, D. W., Joyce, S., Boothby, M., 2003 Antiapoptotic function of NF-kappa B in T lymphocytes is influenced by their differentiation status: roles of Fas, c-FLIP, and Bcl-xL. Cell Death Differ.

Nagarathna, P. K. M., Reena, K., Sriram, R., Wesley, J., 2013. Review on immunomodulation and immunomodulatory activity of some herbal plants. Int. J. Pharm. Sci. Rev. Res. 22(1): 223-230.

Patil, U. S., Jaydeokar, A. V., Bandawane, D. D., 2012 Immunomodulators: A pharmacological review. Int J Pharm Pharm Sci. 4(Suppl 1): 30-36.

Paul, W. E., Selder, R. A., 1998. Lymphocyte responses and cytokine. Cell. 78: 241-244.

Peasura, N., Laohakunjit, N., Kerdchoechuen, O., Vongsawasdi, P., Chao, L. K., 2016. Assessment of biochemical and immunomodulatory activity of sulphated polysaccharides from Ulva intestinalis. International journal of biological macromolecules. 91: 269-277.

Pérez-Recalde, M., Matulewicz, M. C., Pujo, I. C. A., Carlucci, M. J., 2014. In vitro and in vivo immunomodulatory activity of sulfated polysaccharides from red seaweed Nemalion helminthoides. International journal of biological macromolecules. 63: 38-42.

Prasad, A. S., Bao, B., Beck, F. W., Sarkar, F. H., 2002. Zinc enhances the expression of interleukin-2 and interleukin-2 receptors in HUT-78 cells by way of NF-KB activation. J Lab Clin Med. 140: 272-289.

Petry, V., Gaspari, A., 2006. Toll-like receptors and dermatology.International Journal of Dermatology. 8:558-570.

Rankin, J. A., 2004. Biological mediators of acute inflammation. AACN Clinical Issues. 15(1): 3-17.

Redecke, V., Häcker, H., Datta, S. K., Fermin, A., Pitha, P. M., Broide, D. H., Raz, E., 2004. Cutting edge: activation of Toll-like receptor 2 induces a Th2 immune response and 
promotes experimental asthma. The Journal of Immunology. 172(5):2739-2743.

Roitt., 2011. Essential Immunology.12th edition. Oxford: Blackwell ScienceLimited.

Sacca, R., Cuff, C. A., Ruddle, N. H., 1997. Mediators of inflammation. Curr Opin Immunol. 9:851-857.

Schepetkin, I. A., Quinn, M. T., 2006. Botanicalpolysaccharides: Macrophage immunomodulation and therapeuticpotentil. International Immunopharmacology. 6(3): 317-333. doi:10.1016/j.intimp.2005.10.005.

Shan, B. E., Yoshida, Y., Kuroda, E., Yamashita, U., 1999. Brief Communication Immunomodulating activity of seaweed extract on human lymphocytes in vitro. International journal of immunopharmacology. 21(1): 59-70.

Shao, B. M., Xu, W., Dai, H., Tu, P., Li, Z., Gao, A., 2004. Study on the immune receptors for polysaccharides from the roots of Astragalus membranaceus, a Chinese medicinal herb. Biochem.Biophys. Res. Commun. 320(4): 11031111.

Shin, J., Yun, Y., Pyo, S., 2002.Immunostimulanting effect of acidic polyssharides of Panax ginseng on macrophage function. Immunopharmacology and Immunotoxicology. 24: 469-482.

Shizuo, A., 2000. A Toll-Like Receptor Recognized Bacteri. Nature: vol. 408:740-745. Research Institute for Microbial Disesase, Osaka University; Erato of Japan. Shipkova M, Wieland E. 2012. Surface markers of lymphocyte activation and markers of cell proliferation. Clinica chimica acta. 413(17): 1338-1349.

Shu, M. H., Appleton, D., Zandi, K., AbuBakar, S., 2013. Antiinflammatory, gastroprotective and anti-ulcerogenic effects of red algae Gracilaria changii (Gracilariales, Rhodophyta) extract. BMC Complementary and Alternative Medicine. 13(1): 61. doi:10.1186/1472-688213-61.

Soeroso, A., 2007. Sitokin.Jurnal Oftalmogi Indonesia. 5: 171180

Subaryono, S., Perangiangin, R., Suhartono, M. T., Zakaria, F. R., 2017. Imunomodulator activity of alginate oligosaccharides from alginate Sargassum crassifolium. JPHPI. 20(1): 63-73.

Tabarsa, M., Han, J. H., Kim, C. Y., You, S. G., 2012. Molecular characteristics and immunomodulatory activities of water-soluble sulfated polysaccharides from Ulva pertusa. Journal of medicinal food. 15(2):135-144.

Takahashi, A., Watanabe, T., Mondal, A., 2014. Mechanism basedinhibition of cancer metastasis with (-)epigallocatechingallate, Biochem and Biophysical Research Communications. 443(1): 1-6.

Tjandrawinata, R. R., Maat, S., Noviarny, D., 2005. Effect of standardized Phyllanthus niruri extract on changes in immunologic para-meters: correlation between preclinical and clinical studies. Medika XXXI (6): 367-371.

Tsuji, R. F., Hoshino, K., Noro, Y., Tsuji, N. M., Kurokawa, T., Masuda, T., 2003. Suppression of allergic reaction by lambda-carrageenan: toll-like receptor 4/MyD88 dependent and-independent modulation of immunity. Clin Exp Allergy; 33: 249-258.

Ulmer, A. J., Flad, H. D., Rietschel, T., Mattern, T., 2000. Induction of proliferation and cytokine production in human $\mathrm{T}$ lymphocytes by lipopolysaccharide (LPS). Toxicology. 152(1): 37-45.

Usmiati, S., 2017. Modifikasi struktur, ukuran dan bentuk fisikpektin bermetoksil rendah serta pengaruhnya terhadap ketahanan probiotik dan aktivitas sel makrofag RAW264. 7 secara in vitro. [Disertasi]. Bogor. (ID): Institut Pertanian Bogor.

Wang, M. L., Hou, Y. Y., Chiu, Y. S., Chen, Y. H., 2013. Immunomodulatory activities of Gelidium amansii gel extracts on murine RAW 264.7 macrophages. journal of food and drug analysis. 21(4): 397-403.

Wiedosari, E., 2013. Peranan Imunomodulator alami (Aloe vera) dalam sistem imunitas seluler dan humoral. Wartazoa. 17 (4): 165-171.

Wieland, E., 2015. Markers of lymphocyte activation and proliferation. Personalized Immunosuppression in Transplantation, 1st Edition. Role of Biomarker Monitoring and Therapeutic Drug Monitoring. Atlanta, GA: Elesevier: 227-249.

Yamamoto, Y., Gaynor, R. B., 2001. Therapeutic potential of inhibition of the NF-KB pathway in the treatment of inflammation and cancer. J Clin Invest 107: 135-142.

Yan, Z. F., Liu, N. X., Mao, X. X., Li, Y., Li, C. T., 2014. Activation effects of polysaccharides of Flammulina velutipesmycorrhizae on the $\mathrm{T}$ lymphocyte immune function. Journal of Immunology Research1: 1-7.

Yoo, M. S., Shin, J. S., Choi, H. E., Cho, Y. W., Bang, M. H., Baek, N. I., Lee, K. T., 2012. Fucosterol isolated from Undaria pinnatifida inhibits lipopolysaccharide-induced production of nitric oxide and pro-inflammatory cytokines via the inactivation of nuclear factor-KB and p38 mitogen-activated protein kinase in RAW264. 7 macrophages. Food chemistry. 135(3): 967-975.

Zha, X. Q., Lu, C. Q., Cui, S. H., Pan, L. H., Zhang, H. L., Wang, J. H., Luo, J. P., 2015. Structural identification and immunostimulating activity of a Laminaria japonica polysaccharide. International journal of biological macromolecules. 78:429-38.

Zhang, X., Qi, C., Guo, Y., Zhou, W., Zhang, Y., 2016. Toll-like receptor 4-related immunostimulatory polysaccharides: Primary structure, activity relationships, and possible interaction models. Carbohydrate polymers. 149:186206 